ARTICLE HISTORY: Received: October 12, 2021 Accepted: December 06, 2021 Published: December 13, 2021

УДК 373.34

ББК 74.262 .21

\title{
ИСПОЛЬЗОВАНИЕ QR-КОДА В ПРОЦЕССЕ ИЗУЧЕНИЯ С МЛАДШИМИ ШКОЛЬНИКАМИ ИСТОРИЧЕСКИХ ФАКТОВ ОБ ИЗМЕРЕНИИ ВРЕМЕНИ
}

Гребенникова Н.Л.

кандидат педагогических наук, доиент

Косиова С.A.

старший преподаватель

Тихонова О.С.

студентка факультета педагогики и психологии

Стерлитамакский филиал «Башкирского государственного университета»

2. Стерлитамак, Республика Башкортостан

\begin{abstract}
Аннотация. Статья посвящена проблеме изучения с младшими школьниками величины «Время». Авторы предлагают использование исторических данных об измерении времени, закодированных в QR-код, для большей заинтересованности учеников изучением этой сложной для обучающихся в 1-4 классах величины. Приводятся сгенерированные авторами образцы QR-кодов с зашифрованными историческими данными по всем единицам времени для уроков и внеурочных занятий по математике в начальных классах.
\end{abstract}

Ключевые слова: начальная школа, математика, величина «Время», исторические данные, QR-код.

В согласовании с Примерной программой по математике у обучающихся начальных классов должно быть сформировано представление о величинах как об определенных общих свойствах реальных объектов и явлений, какие, в первую очередь в целом, сопряжены с измерением. Как свидетельствуют методические исследования, время считается сложнейшей для освоения учениками величиной ввиду своей непрерывности - «текучести» и невозможности воспринимать время, ощущать его сенсорно - органами чувств. Преимущественно трудно в данном отношении младшим школьникам, которые только учатся ориентации во времени, рационально его применять, планировать собственную деятельность во времени. К тому же единицы времени обладают недесятичным соотношением, что приводит к множественным ошибкам обучающихся при выполнении перехода от одних единиц времени к другим и выполнения операций с ними.

Введение элементов истории при изучении величины «время» дает возможность избавиться от большей части из перечисленных проблем, сделать процесс изучения наиболее увлекательным и осмысленным.

На сегодняшний день образовательный процесс модифицируется под воздействием современного тренда, такого как мобильное обучение - организация процесса обучения с поддержкой гаджетов и смартфонов. Образовательные мобильные приложения, платформы, интернет-курсы, вебинары, онлайн-квесты органически вплетаются в сегодняшнее обучение школьников и более того являются его уже обязательной составляющей. В настоящее время среди разнообразия потенциальных средств в отдельности можно сделать акцент на применение QR-кода в урочной, внеурочной и внешкольной учебной деятельности.

B связи с вышеперечисленным мы предлагает вводить исторические данные, зашифрованные в QR-код, для облегченного и более увлекательного изучения младшими школьниками такой сложной величины, как время.

Под QR-кодом (от англ. Quick Response - быстрый ответ) понимают миниатюрный носитель данных, который хранит текстовую информацию объемом порядка трёх тысяч байт. Эти данные кодируются с помощью специальных программ или сервисов в виде чёрно-белых или цветных квадратов [2, с. 32].

Таким образом, включая QR-код в изучение величины «время», мы достигнем целый ряд целей: внедрить использование электронных ресурсов на уроке, усилить мотивацию обучающихся к познанию сложной величины, повысить общую техническую грамотность.

Существуют множество сервисов для генерирования QR-кодов. Вот некоторые из них [1]: сервис QR coder (http://www.qrcoder.ru); сервис QR code Generator (http://zxing.appspot.com/generator); онлайн-конструктор для создания мобильных решений на базе QR-кодов Creambee (http://creambee.ru/qr-code-generator); cepвис QRMania (http://www.colorqrcode.ru); сервис ColorQrCode (http://www.colorqrcode.ru).

C помощью данных сервисов мы создали несколько QR-кодов с зашифрованными историческими данными по всем единицам времени. Их можно применить на уроках или внеурочных занятиях по математике для закрепления и углубления знаний младших школьников о величине. Представляем вашему вниманию созданные нами образцы:

1. Сведения из энциклопедии «Откуда пошли названия дней недели?» (см. рис. 1). 
2. Видеоролик с историческими данными «Как появилось время: годы, месяцы, сутки, часы, минуты?» (см. рис. 2)

3. Презентация «Счет лет в истории» с историей возникновения века, года и месяца (см. рис. 3).

4)

4. Проект на тему «Время», в котором содержатся исторические данные о всех единицах времени (см. рис.

5. Про историю суток и изобретение часов в видеосюжете «Как изобретали время?» (см. рис. 5)

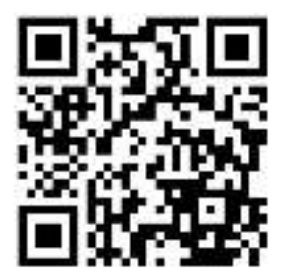

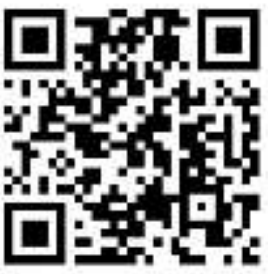

Puc. 1. Puc. 2. Puc. 3 .

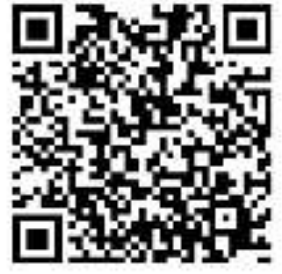

Puc. 4.

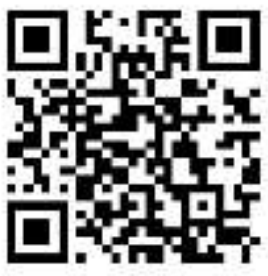

Puc. 5.

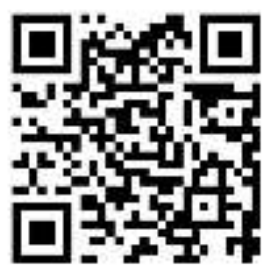

Таким образом, изучение величины «время» младшим школьникам дается нелегко. Для этого эффективным помощником выступает QR-код, в который можно зашифровать исторические данные о времени. Такое средство мобильного обучения содействует легкому и увлекательному усвоению сложнейшей темы в начальных классах и дает возможность оперативно находить нужную информацию о величине «время».

\section{Список литературы}

1. Баданов А.Г. «QR coder». Интерактивности - Web-сервисы для образования. URL: https://sites.google.com/site/badanovweb2/home/qr-coder (дата обращения 10.12.2021)

2. Бурлуцкая H.A. QR-коды как средство повышения мотивации обучения // Наука и перспективы. - 2016. № 1. - C.31-36. 